\title{
Literal framework of Green supply chain Modeling
}

\author{
Sana Elhidaoui ${ }^{* 1}$, Khalid Benhida ${ }^{2}$, Said Elfezazi, and Abdellatif Benabdelhafid, Nadia \\ Hamani $^{3}$ \\ 1, 2 LAPSSII, EST of Safi, Cadi Ayyad University, Morocco \\ LAPSSII, Engineering Sciences, UCAM, Marrakech, Morocco, \\ ${ }^{3}$ LTI (Laboratory of Innovative Technologies), UPJV, France,
}

\begin{abstract}
Background: Supply chain covers a set of logistics components (procurement, storage, production, distribution...). In addition to the classical logistics components, the green supply chain integrates the environmental dimension in all these components.

Nowadays modeling a supply chain by integrating environmental constraints has become an important metrics, in the logistic field for scientists, and also for industrialist in order to meet the customer needs, that has become more and more demanding in terms of respecting environment.

This article aims to summarize some literature studies of the green supply chain and its modeling; afterwards we will expose an overview trough a comparative study about the used methods and approaches in the green supply chains modeling.
\end{abstract}

Key words: Inser green supply chain, environmenta limpacts

\section{INTRODUCTION}

Action on climate change has never been more necessary. Year after year, we remark increasingly hot temperatures recorded impacting our ecosystems and our environment. In this context, the Paris agreement of COP21 entered into force. This decisive statement of intent, born of an unprecedented global consensus, marks a step genuinely meaningful toward a future to low carbon content (CDP Supply Chain Report 2016/2017).

Today, the green supply chain (SC) is one of the wellknown topics of current interest and debate in numerous research projects, but also, for companies whatever their field of application.

To meet the challenge of climate change, companies are thinking about good practices and actions to reduce environmental impacts, such as supply chain modeling (SC) by integrating environmental constraints. The word green supply chain (SC), has become a trend, and a customer expectation [1]. Herein, the customer has also become aware of the importance of protecting environment from products or services impact's offered by companies.

\section{The Green Supply Chain}

At the end of the 1990s, a new topic of research has been appeared: the green SC. Moving from classical SC to the green SC emerged strongly in the early 2000s as a result of climate change, which increasingly requires responsible corporate involvement. The objective is to develop economic and environmental performance by promoting a broad client-supplier relationship [2]. This passage has indeed made it possible to integrate the environment imperatives and to adopt strategies in the sense of sustainable development [3]. The effort focuses exclusively on reducing greenhouse gas emissions, with special attention being given to carbon dioxide $\mathrm{CO} 2$, which is the most liberated gas.

A green SC can be defined as a SC that is based on the concept of sustainable development, and all its activities are mostly ecological, from procurement to distribution of green products, or services that respect the environment, thus the customer-supplier relationship must be based on a common agreement on environmental requirements. Among the factors of development of green SC, the product life cycle, operational life cycle, performance measures, and elements of environmental policy [4]. For instance, lifecycle assessment helps in decision-making by providing means of assessing impacts on human health, ecosystems and natural resources [5].

Green SC management differs from an ordinary SC by adapting decision-making levels to environmental constraints, and a piloting that takes into account environmental risk (i.e. waste management), from 
diverse activities: from procurement, to production, till distribution. Moreover, reverse logistics approaches facilitate the study of a green SC in a different way, considering a closed loop. The green SC management integrates the environmental dimension throughout its management [6] including product design, selection of material sources, production process, and delivery of the finished product to the customer, up to and after the end of the product's life.

\section{$2 \quad$ Green Supply Chain Modeling}

Modeling a supply chain means presenting one or all its entities, in procurement phase, production, distribution or three phases using a method or approach (mathematics, by simulation, or organizational) according to several criteria that depend both on the field of application, the decision levels and also the feasibility of the used approach, in order to detect malfunctions and needs.

The modeling of a classical SC, focuses on economic optimization objectives, although the emergence of recent research that attempts to link SC to the environmental aspect, paved the way for the integration of environmental constraints in the SC modeling that are not always oriented towards economic objectives.

Also linking remanufacturing strategies and greening supply chain [7]. In the following paragraphs, we suggest a summarized bibliographic study and specific to SC modeling integrating environmental constraints. In this literature review we are particularly interested in two main industrial fields; the chemical industry and the canning industry.

\subsection{Green Agro-food (SC) modelling}

The cost of logistics is about $15 \%$ to $30 \%$ of the export or distribution price of agricultural products [8], the agro-food sector, is among the most demanding, in terms of SC management, in particular and more recently to environmental impacts. A significant number of researchers are interested in developing methods for modeling agro-food SC, including environmental constraints.

The article [9] deals with green SC modeling in the agro-food sector, namely, the case of orange juice production SC's, by evaluating the life cycle and multiobjective optimization by genetic algorithms and multicriterion decision-making tools (TOPSIS), taking into account three echelons: supplier, manufacturing and market segments. This study was carried out in order to show the utility of eco-labeling, by integrating environmental constraints into the established model. Taking in consideration the global warming potential expressed in $\mathrm{kg}$, as an example of constraints. On the other hand, this study contributed to the achievement of sustainable agro-food SCs.

Article [10] introduced a new ALADIN simulation environment in a case study of food SC modeling; it proposed an integrated approach to logistical sustainability and food quality analysis. Indeed, this work has integrated sustainability indicators into the simulation models.

As for article [11], it presented the mathematical modeling of an oil Palm SC, with an emphasis on the reverse logistic flow. This paper has dealt with the case of closed loop SC, where the upstream and downstream product flows are simultaneous. The environmental aspect has been taken into account relatively to an objective that integrates energy consumption. After analyzing the results, it appears that the upstream and downstream flows have a positive impact on agro-food $\mathrm{SC}$ in economic and environmental terms.

A green SC model is also proposed by the article [12] and specifically the case of a French agro-food SC, using firstly the AHP method and the aggregation method (the ordered weighted method) to develop a multi-objective mathematical model. This model allows taking into account the three dimensions, in particular the sustainability including the carbon and water footprint. These numerical results, which provide an idea about environmental impact of the studied SC, also provide information on its design.

The article [13] has chosen to model an agro-food SC, using total interactive structural modeling, it is a food waste SC, to derive practical information, in order to improve effectiveness and to take in consideration the protection and conservation of environmental resources.

\subsection{Chemical and automotive industry Green supply chain Modeling}

Logistics costs are about $25 \%$ of the added value for manufacturing sectors [8]. In this case of industry, taking environment into account in SC management includes not only sustainable development, but also mutual economic benefits between customer and company. We propose hereafter several works about methods and tools of modeling such a SC type.

To optimize raw material procurement, article [14] proposed a green SC model by treating the case of a unit of bioethanol in France, from agricultural residues, and annual and perennial crop. By integrating the environmental impacts into the model. After testing several scenarios, this article deduced three types of biomass that generate critical and diversified percentages of GHG (Greenhouse Gas) emissions. It has also shown that GHG emissions can be reduced by up to $60 \%$.

Gao,\& al [15] proposed a hydrocarbon-based biofuels SC modeling in Illinois USA, by optimizing the life cycle of the product using a stochastic approach, more precisely a stochastic model of mixed linear fractional programming, taking as objective function a function minimizing the environmental impact relative to the acquisition, raw material processing, manufacturing, transportation and distribution of the product. 
The cement industry is dealt with in article [16] in Brazil, in order to analyze the interaction between two strategies, one to reduce $\mathrm{CO} 2$ emissions in the atmosphere (the imposition of a price policy on CO2emissions) and the second one the network infrastructure for $\mathrm{CO} 2$ capture and storage, in particular the uncertainty of storage capacity. By using a stochastic model of linear mixed-integer optimization, which allows minimizing the costs of capture, transport and storage of $\mathrm{CO} 2$.

Among the sectors most sensitive to environment, the automotive sector. Article [17] presented a modeling of an automotive SC for decision-making, identification of best practices of ecological and lean SC management in order to improve their eco-efficiency, using a mathematical model that minimizes the negative environmental and economic impacts of the SC.

More generally, article [18] modeled an industrial SC trough a mathematical model of multi-objective optimization, using the Tcgebycheffand weighted sum method, and as objective function, a function minimizing the total cost of $\mathrm{CO} 2$ throughout the SC. The model is solved via CPLEX v12.4 Solver for Microsoft Excel, which helps to determine the model's ability to cope with the trade-offs between costs and environmental problems and to identify its limitation in the case of real size problems.

The article [19] highlighted the need to explicitly evaluate the environmental impact in a closed-loop SC, by treating the case of an electronics manufacturing company; the modeling is performed using the ToBLooM (Triple Bottom Line Optimization Modeling) method. It is a decision-making tool that consists of a multi-objective, mixed integer linear programming model, integrating several decisions, in particular the environmental impact through the life cycle analysis methodology.

To illustrate their model of optimization, Zhao R,\& al [20] took the case of sanitary products SC in China. It is a multi-objective model that minimizes the inherent risk of handling hazardous materials and carbon emissions by proposing three scenarios that generally minimize the costs of carbon emissions. The model parameters are implemented via Big Data analysis using the SPSS19.0 software. These authors [20] have deduced that the best solution for reducing carbon emissions, as well as improving green SC, is optimization.

\subsection{Green SC modeling other domaines}

Sunil Kumar Jauhar,\& al [21] proposed a linear mathematical model solved by the DEA (Data Envelopment) method and a fractional mathematical model solved by the DE (Differential Evolution) method, for an educational SC in India, by adopting an objective function that maximizes the overall efficiency of sustainable SC, taking in consideration environmental aspects.

Article [22] focused on reverse green SC, proposing a linear mixed integer programming (MILP) model, to model a reverse SC of electronic waste recycling, with uncertainty about the collection rate, the exchange rate, and the cost of shipping under carbon constraints.

A goal programming model to design a green SC of instore product sales, is proposed in article [23] by integrating consumer segmentation, which is divided into three categories, green consumers, inconsistent consumers, red consumer, and proposed a resolution of the model by ILOG CPLEX Solver, in order to clearly demonstrate the value and applicability of the proposed model by studying a set of scenarios.

To evaluate the strategies of reduction of the carbon coming from SC in the UK, using an alternative port combination, and multimodal strategies, V.Sanchez Rodriques,\& al [24] presented a simulation model, in five alternative scenarios, aimed to minimize $\mathrm{CO} 2$ emissions, as well as their cost, generated by road freight transport.

In terms of energy saving, article [25] presented a study of the effects of various governmental regulation policies on competition of green supply chains, by formulating twelve mathematical programming models using Stackelberg game between government and supply chains.

SCs modeling have implicitly contributed to the rise of climate change; moreover if the first SC models considered so far environmental constraints, perhaps the climate change could be likely mitigated from current events. In view of the models presented above, it's noted that the CEPLEX solver is the most used as a model resolution, and that $\mathrm{CO} 2$ emissions is the most treated as an indicator or model environmental constraint, thus it's observed that most of works do not take into account simultaneously the three constraints: economic, environmental, and social, besides they have proved a certain willingness to promote the models of SC, or to propose new models, with a consciousness of environmental challenge.

On the other hand, the proposed models testify and approve the lack of a common model of SC modeling, whatever the tools and approaches, each researcher works on his own model, or improve another from a perspective; however, the environmental component will further complicate this lack.

\subsection{Comparative Study}

We summarize the methods and approaches of the above presented models proposed in this paper, depending on the field of application, in the below summary table (Table 1). 
Sana Elhidaoui et al./ Journal of Engineering and Science Research, 3(4) 2019, Pages: 20-27

Tableau 1: Comparative table of the proposedmodels

\begin{tabular}{|c|c|c|c|c|c|}
\hline \multirow{2}{*}{ Research works } & \multicolumn{2}{|l|}{ Modeling } & \multirow{2}{*}{$\begin{array}{l}\text { Environment } \\
\text { al Constraints }\end{array}$} & \multirow[t]{2}{*}{ Indicators } & \multirow[t]{2}{*}{ Resolution } \\
\hline & Type & Model & & & \\
\hline & Agri-food & & & & \\
\hline $\begin{array}{l}\text { Miranda- } \\
\text { Ackerman, et al } \\
\text { [8] }\end{array}$ & Analytic & $\begin{array}{l}\text { Non-linear } \\
\text { integer multi- } \\
\text { objective } \\
\text { model } \\
\text {-Genetic } \\
\text { algorithm and } \\
\text { multi-criterion } \\
\text { decision } \\
\text { making } \\
\text { tools }\end{array}$ & $\begin{array}{l}\text { Eco-labeling } \\
\text { Global } \\
\text { warming } \\
\text { potential }\end{array}$ & $\begin{array}{l}\text { Global } \\
\text { warming } \\
\text { potential }\end{array}$ & M-TOPSIS \\
\hline $\begin{array}{l}\text { Hamid Allaoui et } \\
\text { al, [11] }\end{array}$ & $\begin{array}{l}\text { - Analytic } \\
\text {-Simulation }\end{array}$ & $\begin{array}{l}\text { AHP method } \\
\text { and the } \\
\text { agregation } \\
\text { method (the } \\
\text { ordred } \\
\text { weighted } \\
\text { method) } \\
\quad \text { MILP }\end{array}$ & $\begin{array}{l}\text { Sustainability } \\
\text { including } \\
\text { carbon and } \\
\text { waterfootprin } \\
\mathrm{t}\end{array}$ & $\begin{array}{l}\text { Economic } \\
\text { environme } \\
\text { ntal } \\
\text { socials }\end{array}$ & $\begin{array}{l}\text { LP Solver } \\
\text { CPLEX } \\
\text { Pareto }\end{array}$ \\
\hline $\begin{array}{l}\text { M. Balaji, K. } \\
\text { Arshinder, [12] }\end{array}$ & Organizational & $\begin{array}{l}\text { Total } \\
\text { interactive } \\
\text { structural } \\
\text { modeling } \\
\text { MICMAC } \\
\text { (cross- } \\
\text { multiplication } \\
\text { impact matrix } \\
\text { to a ranking) }\end{array}$ & $\begin{array}{l}\text { Protection } \\
\text { and } \\
\text { conservation } \\
\text { of } \\
\text { environment } \\
\text { al resources }\end{array}$ & - & - \\
\hline $\begin{array}{l}\text { Edgar H.et al, } \\
{[10]}\end{array}$ & Analytic & $\begin{array}{l}\text { Mathematical } \\
\text { modeling }\end{array}$ & $\begin{array}{c}\text { Objective } \\
\text { integrating } \\
\text { energy } \\
\text { consumption }\end{array}$ & - & $\begin{array}{l}\text { Genral Algebric } \\
\text { Modeling } \\
\text { System(GAMS) }\end{array}$ \\
\hline $\begin{array}{l}\text { J.G.A.J.van der } \\
\text { Vorst D.et al, [9] }\end{array}$ & Simulation & $\begin{array}{l}\text { A novel } \\
\text { simulation } \\
\text { environment }\end{array}$ & $\begin{array}{l}\text { Logistic } \\
\text { sustainability }\end{array}$ & - & ALADIN \\
\hline & $\begin{array}{l}\text { Automotive and } \\
\text { chemical industry }\end{array}$ & & & & \\
\hline
\end{tabular}


Sana Elhidaoui et al./ Journal of Engineering and Science Research, 3(4) 2019, Pages: 20-27

\begin{tabular}{|c|c|c|c|c|c|}
\hline $\begin{array}{l}\text { Gao, Jiyao., \& } \\
\text { You, Fengqi. [14] }\end{array}$ & Analytic & $\begin{array}{l}\text { Stochastic } \\
\text { model of mixed } \\
\text { linear } \\
\text { fractional } \\
\text { programming }\end{array}$ & $\begin{array}{l}\text { A function } \\
\text { minimizing } \\
\text { the } \\
\text { environment } \\
\text { al impact } \\
\text { related to } \\
\text { acquisition }\end{array}$ & $\begin{array}{l}\text { GHG } \\
\text { Emission }\end{array}$ & BARON 15 \\
\hline $\begin{array}{l}\text { Bruna Mota et al, } \\
\text { [18] }\end{array}$ & Analytic & $\begin{array}{l}\text { ToBLooM } \\
\text { (Triple Bottom } \\
\text { Line } \\
\text { Optimization } \\
\text { Modeling) } \\
\text { method, } \\
\text { composed of a } \\
\text { mixed integer } \\
\text { linear multi- } \\
\text { objective } \\
\text { programming }\end{array}$ & $\begin{array}{l}\text { Environment } \\
\text { al impact } \\
\text { assessment } \\
\text { using the life } \\
\text { cycle analysis } \\
\text { method. }\end{array}$ & $\begin{array}{l}\text { environme } \\
\text { ntal Impact } \\
\text { Social } \\
\text { indicator } \\
\text { based on } \\
\text { GDP } \\
\text { Economic }\end{array}$ & $\begin{array}{l}\text { GAM } 23.6 \\
\text { CPLEX } 12.0\end{array}$ \\
\hline $\begin{array}{l}\text { Ernesto D.R. et } \\
\text { al, [15] }\end{array}$ & Analytic & $\begin{array}{l}\text { Linear mixed- } \\
\text { integer } \\
\text { optimization } \\
\text { stochastic } \\
\text { model SMILP }\end{array}$ & $\begin{array}{l}\text { Minimize CO2 } \\
\text { storage }\end{array}$ & - & $\begin{array}{l}\text { GAMS } \\
\text { CPLEX }\end{array}$ \\
\hline $\begin{array}{l}\text { Helena Carvalho } \\
\text { et al, [16] }\end{array}$ & Analytic & $\begin{array}{l}\text { Mathematical } \\
\text { modeling } \\
\text { (maximize / } \\
\text { minimize) }\end{array}$ & $\begin{array}{l}\text { Minimize the } \\
\text { negative } \\
\text { environment } \\
\text { al impacts of } \\
\text { SC }\end{array}$ & - & - \\
\hline $\begin{array}{l}\text { Kartin a Puji } \\
\text { Nurjanni et al, } \\
\text { [17] }\end{array}$ & Analytic & $\begin{array}{l}\text { A mathematical } \\
\text { model of multi- } \\
\text { objective } \\
\text { optimization, } \\
\text { MO } \\
\text { the weighted } \\
\text { sum method } \\
\text { Tcgebycheffan } \\
\text { d, }\end{array}$ & $\begin{array}{l}\text { Minimize the } \\
\text { total cost of } \\
\mathrm{CO} 2\end{array}$ & $\begin{array}{l}\text { Total } \\
\text { Emission of } \\
\text { CO2 } \\
\text { Total cost } \\
\text { of financial } \\
\text { expenses }\end{array}$ & $\begin{array}{l}\text { CPLEX v12.4 } \\
\text { Solver for } \\
\text { Microsoft Excel }\end{array}$ \\
\hline $\begin{array}{l}\text { Karine Dufoss et } \\
\text { al, [13] }\end{array}$ & By simulation & $\begin{array}{l}\text { GCM model } \\
\text { (General } \\
\text { circulation } \\
\text { model) }\end{array}$ & $\begin{array}{l}\text { Reduction of } \\
\text { GHG } \\
\text { emissions }\end{array}$ & $\begin{array}{l}\text { GHG } \\
\text { Emission } \\
(\mathrm{CO} 2 / \mathrm{N} 20) \\
\mathrm{kg}\end{array}$ & GERES-EGC \\
\hline $\begin{array}{l}\text { Zhao R, et al, } \\
\text { [19] }\end{array}$ & Analytic & $\begin{array}{l}\text { multi-objectif } \\
\text { Model MO }\end{array}$ & $\begin{array}{l}\text { Minimize the } \\
\text { inherent risk } \\
\text { in handling } \\
\text { hazardous } \\
\text { materials, } \\
\text { and the }\end{array}$ & $\begin{array}{l}\text { Carbon } \\
\text { Emission } \\
\text { Inherent } \\
\text { risk }\end{array}$ & $\begin{array}{l}\text { Big Data analysis } \\
\text { using SPSS19.0 } \\
\text { softwar }\end{array}$ \\
\hline
\end{tabular}


Sana Elhidaoui et al./ Journal of Engineering and Science Research, 3(4) 2019, Pages: 20-27

\begin{tabular}{|c|c|c|c|c|c|}
\hline & & & $\begin{array}{l}\text { carbon } \\
\text { emission }\end{array}$ & & \\
\hline & other fields & & & & \\
\hline $\begin{array}{l}\text { V.Sanchez } \\
\text { Rodriques et al } \\
{[23]}\end{array}$ & By simulation & $\begin{array}{l}\text { simulation } \\
\text { Model, in five } \\
\text { alternative } \\
\text { scenarios }\end{array}$ & $\begin{array}{l}\text { Minimize } \\
\text { CO2 emission }\end{array}$ & - & EXCEL Solver \\
\hline $\begin{array}{l}\text { Zhitao Xu, et al. } \\
\text { [21] }\end{array}$ & Analytic & $\begin{array}{l}\text { Integrated } \\
\text { linear mixed } \\
\text { programming } \\
\text { model (MILP) }\end{array}$ & $\begin{array}{l}\text { Carbon } \\
\text { Emission }\end{array}$ & - & $\begin{array}{l}\text { GAMS } \\
\text { CPLEX } 12.5\end{array}$ \\
\hline $\begin{array}{l}\text { Sunil Kumar } \\
\text { Jauhar et al, [20] }\end{array}$ & Analytic & $\begin{array}{l}\text { Linear } \\
\text { mathematical } \\
\text { model } \\
\text { Fractional } \\
\text { mathematical } \\
\text { model }\end{array}$ & $\begin{array}{l}\text { Maximize the } \\
\text { global } \\
\text { effictivness of } \\
\text { sustainable } \\
\text { chain }\end{array}$ & - & $\begin{array}{l}\text { DEA method } \\
\text { (Data } \\
\text { Envelopment) } \\
\text { ED method } \\
\text { (Differential } \\
\text { Evolution) }\end{array}$ \\
\hline $\begin{array}{l}\text { Coskun Set al. } \\
\text { [22] }\end{array}$ & Analytic & $\begin{array}{l}\text { Goal } \\
\text { programming } \\
\text { Model }\end{array}$ & $\begin{array}{l}\text { Consumers } \\
\text { segmentation, } \\
\text { (green } \\
\text { consumers, } \\
\text { inconsistent } \\
\text { consumers, } \\
\text { red } \\
\text { consumers) }\end{array}$ & - & $\begin{array}{l}\text { ILOG CPLEX } \\
\text { Solver }\end{array}$ \\
\hline & & & & & \\
\hline
\end{tabular}

\section{Conclusion}

Considering examples cited in this paper, we can conclude that the reduction of costs is inseparable from the reduction of environmental impacts. Green SC management is attempting to increase economic returns by reducing the environmental impact. Indeed, several companies worldwide are increasingly moving towards action plans to protect the environment, through the adoption of the best standards, and environmental standards, including the modeling of green SC. In this paper we have focused on modeling green SC, by presenting a brief literature review, and in a second step we proposed models of green SC according to the fields of application. In perspectives we propose as future research works:

- Most models only take into account CO2 emissions, hence the need to generalize the modeling by integrating all the environmental constraints arising from the supply chain.

- Establish a standard green SC modeling procedure, taking into account environmental analysis, regardless of the used approach or tool.

- Then we aim to propose to integrate social sustainability in the green supply chain modeling, taking as a starting point the research work of Tamara Popovic, \& al, [26]. 


\section{REFERENCES}

[1] Zhaofu Hong, Xiaolong Guo, Green product supply chain contracts considering environmental responsibilities, Omega (2018), doi: 10.1016/j.omega.2018.02.010

[2] 2Qinghua Zhu, Raymond P. Cote, Integrating green supply chain management into an embryonic eco-industrial development: a case study of the Guitang Group, Journal of Cleaner Production 12 (2004) 1025-1035.

[3] Larisa Ivascu, Marian Mocan, Anca Draghici, Attila Turi, Simona Rus, Modeling the green supply chain in the context of sustainable Development, Elsevier(2015), Pages 702 708.

[4] Joseph Sarkis, A strategic decision framework for green supply chain management, Journal of Cleaner Production 11 (2003) 397-409.

[5] Jolliet, O., Saadé, M., Crettaz, P.,. Analyse du cycle de vie: comprendre et réaliser un écobilan. Presses polytechniques et universitaires romandes(2010), Lausanne.

[6] Srivastava, S.K., Green supply-chain management: a state-of-the-art literature review, International Journal of Management Reviews(2007), vol. 9 (1), 53-80.

[7] Jie Wei§, Yue Wang§, Jing Zhao, Interaction between greening and remanufacturing strategies in a manufacturer-retailer supply chain, Journal of Cleaner Production (2018), doi: 10.1016/j.jclepro.2018.04.080.

[8] Said Kammas, Pratiques de développement durable chez les prestataires logistiques marocains : quel levier de performance globale ?, Thèse de doctorat, Université Paul Valéry Montpellier III, (2015). Français

[9] Miranda-Ackerman, M.A ., Azzaro-Pantel, C.,.Aguilarlasserre, A.A., Agreen supply chain network design framework for the processed food industry:application to the orange juice agrofood cluster,Computer \& Industrial Engineering(2017), doi:http//dx.doi.org/10/1016/j.cie.2017.04.031

[10] J.G.A.J.van der Vorst D.-J.van deer zee S.O.Tromp, Delivering Performance in Food Supply chains, Woodhead Publishing Series in Food Science,Technologiy and Nutrition(2010),,Page 387-415.(à supprimer)

[11] Edgar H.Alfonso-Lizarazo.Jairo R.MontoyaTorres Edgar Gutiérrez-Franco,Modeling reverse logistics process inthe agro-industrial sector :The case of the palm oil supply chain, ELSEVIER,Volume 37, issue23,1Decembre 2013,Pages 9652-9664.
[12] Hamid Allaoui, Yuhan Guo, Alok Choudhary, Jacqueline Bloemhof,SustainableAgroFoodSupplyChainDesignUsing TwoStageHybridMulti-ObjectiveDecision-Making Approach, Computers and Operations Research (2016), doi: 10.1016/j.cor.2016.10.012

[13] M. Balaji, K. Arshinder,Modeling the causes of food wastage in Indian perishable food supply Chain, Elsevier(2016),Pages 09213449, doi :10.1016/j.resconrec.2016.07.016.

[14] Karine Dufoss e, Jean-Louis Drouet, Benoît Gabrielle, Agro-ecosystem modeling can aid in the optimization of biomass feedstock supply, Elsevier(2016),Pages 1364-8152 doi $: 10.1016 / j$.envsoft.2016.07.014.

[15] Gao, Jiyao., \& You, Fengqi., Modeling Framework and Computational Algorithm for Hedging Against Uncertainty in Sustainable Supply Chain Design using Functional-UnitBased Life Cycle Optimization.Computers and Chemical

Engineeringhttp://dx.doi.org/10.1016/j.compc hemeng.2017.05.021.

[16] Ernesto D.R. Santibanez-Gonzalez, A modelling approach that combines pricing policies with a carbon capture and storage supply chain network, Elsevier(2017),Pages 0959-6526,

dx.doi.org/10.1016/j.jclepro.2017.03.181.

[17] Helena Carvalho,Kannan Govindanb, Susana G. Azevedo, Virgílio Cruz-Machado, Modelling green and lean supply chains: An eco-efficiency perspective, Elsevier(2016),Pages 0921-3449, http://dx.doi.org/10.1016/j.resconrec.2016.09. 025 .

[18] Kartin a Puji Nurjanni, Maria S. Carv alho and Lino Costa, Green supply ch ain design : a math emat ical modelling approach based on a mul ti -objective optimization model, Intern. Journal of Production Economics, http://dx.doi .org/10.1016/ j .i jpe.2016.08.028.

[18] Bruna Mota, Maria Isabel Gomes, Ana Carvalho,Ana Paula Barbosa-Povoa, Sustainable supply chains: an integrated modelling approach under uncertainty, Omega (2017), doi: 10.1016/j.omega.2017.05.006.

[19] Zhao R, Liu Y, Zhang N, Huang T, An Optimization Model for Green Supply Chain Management by Using a Big Data Analytic Approach, Journal of Cleaner 
Production(2016), doi:10.1016/j.jclepro.2016.03.006.

[20] Sunil Kumar Jauhar, Millie Pant, Atulya K.Nagar,Sustainable educational supply chain performance measurement through DEA and differential evolution: A case on Indian HEI, Journal of Computational Science http://dx.doi.org/10.1016/j.jocs.2016.10.007.

[21] Zhitao Xu, Adel Elomri, Shaligram Pokharel, Qin Zhang, X.G. Ming, Wenjie Liu, Global reverse supply chain design for solid waste recycling under uncertainties and carbon emission constraint, Elsevier(2017),dx.doi.org/10.1016/j.wasman.2 017.02.024,0956-053.

[22] Coskun S, Ozgur L, Polat O, Gungor A, A Model Proposal for Green Supply Chain Network Design Based On Consumer Segmentation, Journal of Cleaner
Production(2015), $\quad$ doi:10 $\quad .1016$ /j.jclepro.2015.02.063.

[23] V.Sanchez Rodriques, S.Pettit, I.Harris, A.Beresford, M.Piecyk, Z.Yang, A.Ng,, UK supply carbon mitigation strategies using alternative ports and multimodal freight transport operations, ELSEVIER(2015), doi: 10.1016/j.jclepro.2014.12.013.

[24] Ashkan Hafezalkotob, Modelling intervention policies of government in price-energy saving competition of green supply chains, Computers \& Industrial Engineering (2018), doi: https://doi.org/10.1016/j.cie.2018.03.031

[25] Tamara Popovic , Ana Barbosa-Povoa , Andrzej Kraslawski , Ana Carvalho, Quantitative indicators for social sustainability assessment of supply chains, ELSEVIER(2018),doi.org/10.1016/j.jclepro.2 018.01.1 